\title{
PENGARUH PENDIDIKAN PERKOPERASIAN DAN KUALITAS PELAYANAN KOPERASI TERHADAP PARTISIPASI ANGGOTA PADA KOPERASI BMJH BESUKI TULUNGAGUNG
}

\author{
Nur Aini' ${ }^{1}$, Muhammad Anasrulloh² \\ nuraiiniih19@gmail.com¹ \\ anasrullohm7@gmail.com²
}

\section{Fakultas Sosial dan Humaniora Universitas Bhinneka PGRI}

\begin{abstract}
Abstrak
Penelitian ini bertujuan untuk mengetahui pengaruh pendidikan perkoperasian dan kualitas pelayanan koperasi terhadap partisipasi anggota pada Koperasi BMJH Besuki Tulungagung. Penelitian ini termasuk jenis penelitian kuantitatif dengan populasi seluruh angggota Koperasi BMJH besuki Tulungagung yang berjumlah 65 anggota. Pengambilan sampel menggunakan metode simple random sampling dengan hasil 55 anggota. Metode pengumpulan data menggunakan dokumentasi dan Kuisioner. Metode analisis data dalam penelitian ini terdiri dari uji instrument, uji asumsi klasik, uji analisis linier berganda dan uji hipotesis. Hasil penelitian ini menunjukkan bahwa sebesar 26,6\% partisipasi anggota dipengaruhi oleh pendidikan perkoperasian dan kualitas pelayanan koperasi dan $73,4 \%$ dipengaruhi oleh variabel lain
\end{abstract}

Kata Kunci: Partisipasi Anggota, Pendidikan Perkoperasian dan Kualitas Pelayanan Koperasi

\section{PENDAHULUAN}

Dari tahun ke tahun perkembangan jasa keuangan bank maupun non-bank semakin menjadi perhatian masyarakat. Hal ini dapat dilihat dari semakin bertambahnya jumlah partisipasi di lembaga keuangan bank maupun non-bank. Untuk memenuhi dan melangsungkan usahanya, masyarakat tidak lepas dari peran lembaga keuangan. Masyarakat yang bergerak di bidang usaha mikro dan kecil, mereka condong menggunakan jasa lembaga keuangan non-bank. Salah satu lembaga keuangan non-bank yang banyak diminati masyarakat adalah koperasi.

Koperasi BMJH berdiri pada tanggal 8 Agusutus 2020 yang bertempat di Jl. Neyama RT. 006 RW. 001 Desa Besuki Kec. Besuki Kab. Tulungagung Jawa Timur. Koperasi BMJH termasuk koperasi konsumen dimana koperasi tersebut melaksanakan kegiatan bagi anggota dalam penyediaan barang dan jasa yang dibutuhkan anggota.

Pada Koperasi ada istilah "dari oleh untuk anggota", yang artinya anggota merupakan pemilik, pengelola sekaligus sebagai pengguna barang dan jasa yang dihasilkan oleh koperasi. Sehingga berkembang atau tidaknya sebuah koperasi tergantung oleh kontributif dari anggota atau sering disebut partisipasi anggota. Partisipasi anggota sebagai pemilik diantaranya partisipasi dalam bentuk modal koperasi, penyampaian kritik dan saran serta pengawasan jalannya usaha koperasi (Trisuladana \& Suparman, 2017).

Partisipasi anggota merupakan peran penting demi berjalannya kegiatan berkoperasi, karena anggota merupakan pemilik juga pelanggan. Koperasi sebagai badan keuangan non-bank yang dibentuk oleh anggota untuk menggapai manfaat tertentu melalui partisipasi. Partisipasi dibutuhkan untuk mengurangi kinerja yang buruk, mencegah penyimpangan dan membuat 
pemimpin koperasi bertanggung jawab. Partisipasi anggota sering dianggap baik sebagai alat pengembangan maupun sebagai tujuan akhir itu sendiri. Beberapa peneliti meyakini bahwa partisipasi adalah kebutuhan hak dan asasi manusia.

Partisipasi anggota dipengaruhi oleh beberapa faktor yaitu pendidikan perkoperasian, kualitas pelayanan koperasi, kepuasan anggota, tingkat kepercayaan anggota, lingkungan usaha, motivasi, pengetahuan koperasi, dan minat berkoperasi. Faktor utama yang mempengaruhi partisipasi anggota pada koperasi adalah kualitas pelayanan koperasi. Pelayanan koperasi terhadap anggota harus disesuaikan dengan kebutuhan anggotanya secara berlanjut.

Kualitas pelayanan diartikan sebagai perilaku produsen dalam rangka memenuhi kebutuhan juga keinginan konsumen demi tercapainya kepuasan yang akan dirasakan konsumen itu sendiri. Menurut (Maghfur, 2018) kualitas pelayanan digambarkan sebagi bentuk sikap, tetapi tidak sama dengan kepuasan, yang dihasilkan dari perbandingan antara harapan konsumen dengan kemampuan perusahaan. Kualitas berfouks pada manfaat yang diciptakan bagi pelangan, dan produktivitas mengacu pada biatas mengacu pada biaya yang dikeluarkan oleh perusahaan. (Subiyantoro, 2020) menjelaskan bahwa pelayanan yang bagus terhadap anggota dapat mendorong dalam meningkatkan partisipasi anggota.

Pendidikan koperasi merupakan salah satu prinsip dan kewajiban bagi koperasi. Oleh sebab itu, anggota berhak mendapat pengetahuan dan pemahaman tentang koperasi untuk dipersiapkan menjadi penerus anggota koperasi yang lebih baik (Ramadhan, 2018). Faktor pendidikan perkoperasian merupakan unsur penting dalam perkoperasian untuk mendidik anggota koperasi agar lebih memahami seluk beluk koperasi, dan juga menambah wawasan, pengetahuan mengenai koperasi dengan harapan agar anggota dapat berperan secara aktif dalam berkoperasi.Dalam Undang-Undang Nomor 17 tahun 2012 tentang perkoperasian dijelaskan bahwa koperasi memiliki prinsip, salah satunya yaitu koperasi menyelenggarakan pendidikan dan pelatihan bagi anggota, pengawas, pengurus, dan karyawan, serta menambah informasi kepada masyarakat tentang jati diri, kegiatan, dan kemanfaatan koperasi.

Berdasarkan dokumen yang ada dan hasil observasi yang telah dilakukan, Koperasi BM JH terbukti ada kurangnya pasrtisipasi anggota pada saat pembayaran simpanan pokok dan simpanan wajib. Partisipasi anggota ini diukur melalui indicator: partisipasi anggota dalam permodalan, partisipasi anggota dalam membatu modal koperasi disamping simpanan pokok dan simpanan wajib sesuai dengan kemampuan masing-masing, partisipasi anggota dalam menggunakan jasa atau pelayanan koperasi, partisipasi anggota dalam menghadiri rapat-rapat dan pertemuan secara aktif.

Kualitas pelayanan di koperasi BM JH dirasa masih belum maksimal. Hal ini terlihat dari para anggota yang masih mengeluh tentang barang yang disediakan oleh koperasi belum sesuai dengan apa yang dibutuhan anggota, sehingga tidak semua anggota memanfaatkan jasa yang telah disiapkan. Oleh karena itu, partisipasi anggota pada Koperasi BMJH menjadi berkurang. Pendidikan perkoperasian ini diukur melalui indicator: keterlibatan anggota dalam pendidikan perkoperasian, kesesuaian materi dengan anggota yang dibutuhkan anggota, dan manfaat yang diperoleh anggota.

Tidak hanya kualitas pelayanan koperasi yang dirasa belum maksimal, partisipasi anggota dalam pendidikan perkoperasian juga dirasa masih kurang, karena pada saat diadakanya acara pendidikan perkoperasian banyak dari anggota yang tidak hadir. Kualitas pelayanan ini diukur melalui indicator: daya tanggap (responsivnes), keandalan (reliability), empati (empaty). Permasalahan dalam penelitian ini adalah seberapa besar pengaruh pendidikan perkoperasian dan kualitas pelayanan koperasi terhadap partisipasi anggota. 


\section{METODE PENELITIAN}

Penelitian ini termasuk penelitian jenis kuantitatif dimana data diukur dalam suatu skala numerik (angka). Teknik analisis data dalam penelitian ini terdiri dari uji instrument, uji asumsi klasik, uji regresi analisis linier berganda, uji hipotesis dan uji koefisien determinasi dengan bantuan program computer yaitu SPSS ver 21. Data dalam penelitian ini diperoleh dari dokumen, observasi dan kuesioner yang dibagikan kepada seluruh sampel anggota Koperasi BMJH Besuki Tulungagung

\section{PEMBAHASAN}

Analisis regresi linier berganda mempunyai tujuan untuk menganalisa adakah pengaruh dari variabel yang diteliti, khususnya variabel yang mempunyai hubungan sebab akibat yaitu antara variabel dependen dengan variabel independent.

Tabel 1. Hasil Anallisis Regresi Linier Berganda

\begin{tabular}{|c|c|c|c|c|c|c|}
\hline \multicolumn{7}{|c|}{ Coefficients $^{a}$} \\
\hline \multirow{2}{*}{\multicolumn{2}{|c|}{ Model }} & Unst & dardized Coefficients & Standardized Coefficients & \multirow[b]{2}{*}{$t$} & \multirow[b]{2}{*}{ Sig. } \\
\hline & & $B$ & Std. Error & Beta & & \\
\hline \multirow[t]{3}{*}{1} & (Constant) & .083 & 4.244 & & .019 & .985 \\
\hline & Pendidikan Perkoperasian & .712 & .202 & .426 & 3.530 & .001 \\
\hline & Kualitas Pelayanan Koperasi & .222 & .110 & .243 & 2.017 & .049 \\
\hline
\end{tabular}

a. Dependent Variable: Partisipasi Koperasi

(Sumber: Data Penelitian)

Nilai konstanta sebesar 0,083 yang artinya apabila variabel pendidikan perkoperasian (X1) dan variabel kualitas pelayanan $(\mathrm{X} 2)$ bernilai 0 , maka variabel partisipasi anggota $(\mathrm{Y})$ nilainya sebesar 0,083 dengan asumsi variabel yang lain nilainya konstan. Koefisien regresi pendidikan perkoperasian pada persamaan di atas diperoleh sebesar 0,712 yang berarti apabila skor pada variabel pendidikan perkoperasian meningkat 1 satuan maka partisipasi anggota akan meningkat sebesar 0,712 dengan asumsi variabel yang lain nilainya konstan. Koefisien regresi kualitas pelayanan koperasi pada persamaan di atas diperoleh sebesar 0,222 yang berarti apabila skor pada variabel kualitas pelayanan koperasi meningkat 1 satuan maka partisipasi anggota akan meningkat sebesar 0,222 dengan asumsi variabel yan lain nilainya konstan

Tabel 2. Hasil Uji T (Uji Parsial)

\begin{tabular}{|c|c|c|c|c|c|}
\hline & & Coefficients ${ }^{\mathrm{a}}$ & & & \\
\hline Model & Unst & dized Coefficients & Standardized Coefficients & $t$ & Sig. \\
\hline & $B$ & Std. Error & Beta & & \\
\hline (Constant) & .083 & 4.244 & & .019 & .985 \\
\hline Pendidikan Perkoperasian & .712 & .202 & .426 & 3.530 & .001 \\
\hline Kualitas Pelayanan Koperasi & .222 & .110 & .243 & 2.017 & .049 \\
\hline
\end{tabular}

(Sumber: Data Penelitian)

Dari Tabel 2 diketahui (1)Nilai sig. pendidikan perkoperasian 0,001<0,05 dan nilai thitung sebesar 3,530 > 2,007, maka $\mathrm{H}_{0}$ ditolak dan $\mathrm{H}_{\mathrm{a}}$ diterima. Jadi dapat disimpulkan bahwa pendidikan perkoperasian (X1) bepengaruh secara parsial terhadap partisipasi anggota (X2). (2)Nilai sig. pendidikan perkoperasian 0,049 $<0,05$ dan nilai thitung sebesar 2,017 > 2,007, maka $\mathrm{H}_{0}$ ditolak dan $\mathrm{H}_{\mathrm{a}}$ diterima. Jadi dapat disimpulkan bahwa kualitas pelayanan koperasi (X2) bepengaruh secara parsial terhadap partisipasi anggota (X2). 
Tabel 3. Hasil Uji F (Uji Simultan)

\begin{tabular}{lllllll}
\multicolumn{7}{c}{ ANOVA $^{\mathrm{a}}$} \\
\hline Model & \multicolumn{7}{c}{ Sum of Squares } & df & Mean Square & $\mathrm{F}$ & Sig. \\
\hline \multirow{3}{*}{1} & Regression & 67.132 & 2 & 33.566 & 10.760 & $.000^{\mathrm{b}}$ \\
\cline { 2 - 7 } & Residual & 162.214 & 52 & 3.119 & & \\
\cline { 2 - 6 } & Total & 229.345 & 54 & & & \\
\hline \multicolumn{2}{l}{ a. Dependent Variable: Partisipasi Koperasi } \\
$\begin{array}{l}\text { b. Predictors: (Constant), Kualitas Pelayanan Koperasi, Pendidikan Perkoperasian } \\
\text { (Sumber: Data Penelitian) }\end{array}$
\end{tabular}

Dari tabel 3. Diatas diketahui: Nilai Sig $0,000<0,05$ dan nilai fitung sebesar $10,760>3,17$, maka $\mathrm{H}_{0}$ ditolak dan $\mathrm{H}_{\mathrm{a}}$ diterima sehingga dapat disimpulkan bahwa adanya pengaruh secara simultan antara variabel kualitas pelayanan koperasi $(\mathrm{X} 2)$ terhadap variabel kualitas pelayanan $(\mathrm{Y})$.

Tabel 4. Hasil Uji Korfisien Determinasi

\begin{tabular}{ccccc}
\multicolumn{2}{l}{ Model Summary } \\
\hline Model & $\mathrm{R}$ & $\mathrm{R}$ Square & Adjusted R Square & Std. Error of the Estimate \\
\hline 1 & $.541^{\mathrm{a}}$ & .293 & .266 & 1.766 \\
\hline
\end{tabular}

a. Predictors: (Constant), Kualitas Pelayanan Koperasi, Pendidikan Perkoperasian

Dari tabel 4. Diatas diketahui Nilai Adjusted R Square sebesar 0,266, hal ini berarti bahwa variabel partisipasi anggota $(Y)$ sebesar $26,6 \%$ dipengaruhi oleh variabel pendidikan perkoperasian (X1) dan variabel kualitas pelayanan koperasi (X2).

\section{SIMPULAN}

1. Terdapat pengaruh positif dan signifikan antara pendidikan perkoperasian terhadap partisipasi anggota pada Koperasi BM JH Besuki Tulungagung sesuai dengan nilai thitung sebesar 3,530 $>$ tabel sebesar 0,001 dan koefisien regresi 0,426 (positif).

2. Terdapat pengaruh positif dan signifikan antara kualitas pelayanan koperasi terhadap partisipasi anggota pada Koperasi BM JH Besuki Tulungagung sesuai dengan nilai thitung sebesar 2,017 > ttabel 0,049 dan koefisien regresi 0,243 (positif).

3. Terdapat pengaruh positif dan signifikan antara kualitas pelayanan koperasi terhadap partisipasi anggota pada Koperasi BM JH Besuki Tulungagung sesuai dengan nilai fhitung sebesar 10,760 > $f_{\text {tabel }}$ sebesar 0,000.

4. Koefsien determinasi $\left(R^{2}\right)$ sebesar 0,266 yang berarti bahwa sekitar $26,6 \%$ variasi pada variabel partisipasi anggota mampu diterangkan oleh kedua variabel pendidikan perkoperasian dan kualitas pelayanan koperasi secara bersama-sama. Sedangkan sisanya yaitu sebesar $73,4 \%$ diterangkan oleh variasi lain di luar model.

\section{SARAN PENGEMBANGAN PENELITIAN LANJUT (FUTURE RISET)}

Dilihat dari hasil penelitian ini, sebesar $73,4 \%$ partisipasi anggota dipengaruhi oleh variabel lain yang tidak dijelaskan dalam penlitian ini, oleh sebab itu bagi peneliti selanjutnya mungkin dapat menambah variabel baru seperti pengetahuan koperasi, tingkat kepuasan anggota, tingkat kepercayaan anggota, loyalitas anggota, dan lain-lain, juga dapat menggunakan metode penelitian yang lebih sesuai, serta mencari hasil analisis data yang lebih signifikan, sehingga mendapatkan hasil penelitian yang lebih memuaskan 


\section{DAFTAR RUJUKAN}

Maghfur, M. (2018). Citra Lembaga Keuangaan dan Kualitas Terhadap Pemilihan Pembiayaan Rahn di Koperasi. QIEMA (Qomaruddin Islamic Economy Magazine), 4(2), 168-169.

Ramadhan, D. D. (2018). Pelaksanaan Pendidikan Koperasi Dan Partisipasi Anggota Koperasi Mahasiswa (Kopma) Universitas Negeri Surabaya. Jurnal Pendidikan Ekonomi (JUPE), 6(3). https://doi.org/10.26740/jupe.v6n3.p

Subiyantoro, L. P. A. S. dan H. (2020). Pengaruh Kualitas Pelayanan terhadap Keberhasilan Koperasi melalui Partisipasi Anggota sebagai Variabel Intervening. 5, 111-119.

Trisuladana, R., \& Suparman, A. (2017). Pengaruh Pendidikan Perkoperasian Dan Komitmen Organisasi Terhadap Partisipasi Anggota Koperasi Cu Pundhi Arta. JBTI : Jurnal Bisnis Teori Dan Implementasi, 8(1), 73-83. https://doi.org/10.18196/bti.81084 